tion, and observations of natural history of the disease. Am J Roentgenol 104:274-282, 1968

5. Leadbetter WF, Burkland CE: Hypertension in unilateral renal disease. J Urol 39:611-626, 1938

6. Momose KJ, New FJ: Non-atheromatous stenosis and occlusion of the internal carotid artery and its main branches. Am J Roentgenol Radium Ther Nucl Med 118:550-556, 1973

7. Osborn AG, Anderson RE: Angiographic spectrum of cervical and intracranial fibromuscular dysplasia. Stroke 8:617-626, 1977

8. Palubinskas AJ, Ripley HR: Fibromuscular hyperplasia in extrarenal arteries. Radiology 82:451-454, 1964

9. Rainer WG, Cramer GC, Newby JP, et al: Fibromuscular hyperplasia of the carotid artery causing positional cerebral ischemia. Ann Surg 167:444-446, 1968

10. Roberson GH, Scott WR, Rosenbaum AE: Thrombi at the site of carotid stenosis. Radiology 109:353-356, 1973

11. Sandok BA, Houser OW, Baker HL Jr, et al: Fibromuscular dysplasia. Neurologic disorders associated with disease involving the great vessels in the neck. Arch Neurol 24:462466,1971

12. Sautler RD: Rapid resolution of pulmonary emboli. Dis Chest $52: 825,1967$

13. Seibert CE, Swanson WB: Lysis of thrombus in internal carotid artery in the neck. Report of a case. Acta Radiol [Suppl] 347:271-275, 1975

\section{Lidase Treatment of Spinal Cord Transected Rats}

Timothy F. Kowalski, BS, H. Lee Vahlsing, MS, and Earl R. Feringa, MD

Russian investigators have recently reported clinical recovery of enzyme treated, spinal cord transected rats. Using the exact protocols outlined by Matinian and Andreasian, we repeated a portion of their experiment using a Lidase preparation manufactured in the USSR. Animals were evaluated for return of bladder function, clinical evidence of hind limb motor function, cortical evoked response after sciatic nerve stimulation, and axonal transport of cortically injected tritiated proline by regenerated corticospinal axons.

The only difference between treated and control animals was that the mean total body weight of the treated animals increased more than that of controls ( $p$ $<0.05$ ). No animal walked, had return of voluntary motor activity, showed cortical evoked response, or

From the Departments of Neurology and Pathology, Ann Arbor Veterans Administration and University of Michigan Medical Centers, Ann Arbor, MI.

Accepted for publication Jan 24, 1979.

Address reprint requests to Dr Feringa, Chief, Neurology Service (127), Veterans Administration Medical Center, 2215 Fuller Rd, Ann Arbor, MI 48105. had evidence for transport of tritiated proline over regenerated corticospinal axons.

Kowalski TF, Vahlsing HL, Feringa ER: Lidase treatment of spinal cord transected rats.

Ann Neurol 6:78-79, 1979

Russian investigators [3, 4] have reported that enzyme treatment facilitates axonal regeneration and return of function in spinal cord transected rats. Matinian and Andreasian [3] have stated that use of the enzyme preparation Lidase [1] is effective in enhancing axonal regeneration and promoting functional return. In a previous experiment [2] using the exact protocols of Matinian and Andreasian's two most successful enzyme treatment paradigms, we were unable to duplicate their results. However, since we used enzymes manufactured in the United States, it remained possible that an unknown factor contained in the Russian-produced enzymes could have been responsible for the reported regeneration.

For this experiment we obtained Lidase prepared in the Soviet Union. Following Matinian and Andreasian's protocol exactly, we sought to determine if this preparation was effective in enhancing axonal regeneration in our laboratory.

\section{Materials and Methods}

Six-week-old albino isogeneic female rats, descended from Wistar stock, were used in the experiment. Each weighed approximately $125 \mathrm{gm}$. The surgical techniques utilized were identical to those described in our previous enzyme experiment [2].

Animals were treated either with Lidase, following the protocol of Matinian and Andreasian, or with the enzyme vehicle only. A stock solution of Lidase was prepared according to the package insert directions [5]. One ampoule containing $64 \mathrm{U}$ of dried enzyme powder was dissolved in 2 $\mathrm{ml}$ of Novocain: a $0.5 \%$ sterile procaine hydrochloride solution with $1 \mathrm{mg}$ of sodium hydrosulfite per milliliter and sodium chloride for isotonicity. The volume of solution required for the proper $32 \mathrm{U}$ per kilogram dosage for each animal was further diluted with $0.9 \%$ saline so that each animal received an equal $0.5 \mathrm{ml}$ injection subcutaneously over the site of spinal cord transection. Control animals received similar injections without enzyme.

The procedures used for evaluating bladder function, clinical activity, electrophysiological response, and axonal flow of radioisotopic proline were identical to those described previously [2].

\section{Results}

The interval between cordotomy and return of reflex bladder function was not significantly different between treated and control animals (Table). No significant differences in clinical variables were found when treated animals were compared to controls except that the treated animals weighed more than the 
Return of Bladder Function

\begin{tabular}{lll}
\hline & $\begin{array}{l}\text { No. } \\
\text { of } \\
\text { Days }\end{array}$ & Mean \\
\hline $\begin{array}{l}\text { This study } \\
\text { Lidase }(\mathbf{N}=14)\end{array}$ & $11-15$ & 12.80 \\
$\quad \begin{array}{l}\text { Control }(\mathbf{N}=15) \\
\text { Matinian and } \\
\quad \begin{array}{l}\text { Andreasian's results } \\
\text { (groups combined) }\end{array}\end{array}$ & $10-14$ & 12.33 \\
$\begin{array}{l}\text { Treated }(\mathbf{N}=248) \\
\text { Control }(\mathbf{N}=94)\end{array}$ & $6-16$ & \\
\hline
\end{tabular}

controls $(p<0.05)$. No significant changes in function or physical condition occurred during the evaluation period within any of the groups except that muscle atrophy and mean total body weight both increased with time in each group. None of the animals walked.

No animal in the experiment showed a cortical evoked response as measured by our method [2]. No significant differences were observed between treated and control groups in axoplasmic flow of tritiated proline by regenerated axons as determined by the mean value of the ratio of disintegrations per minute distally versus proximally $(0.033$ in the Lidase group, 0.037 in controls; $p=0.77$ ).

\section{Discussion}

Many believe that mesenchymal and neuroglial scars, which form after central nervous system trauma, act as a barrier blocking the passage of regenerating axons through the site of injury. Matinian and Andreasian believe collagenous scar is the type primarily responsible for blocking regenerating axon sprouts. To alter this barrier, they have utilized various fibrinolytic and proteolytic enzymes that break up the connective tissue components of scar.

One of the enzymes Matinian and Andreasian used was Lidase. Lidase is reported to act specifically on the substrate hyaluronic acid [1]. Hyaluronic acid is an acid mucopolysaccharide found in the extracellular ground substance of connective tissue in vertebrates. As the concentration of hyaluronic acid in scar tissue increases, the scar tissue's permeability decreases. Lidase is reported to increase permeability by depolymerizing the hyaluronic acid found in scar tissue [3].

Our results fail to confirm the beneficial effects of Lidase therapy on CNS regeneration reported by Matinian and Andreasian. They reported that treated animals, which later showed positive signs of regeneration, regained bladder function earlier than controls. We found no difference. They reported that their Lidase-treated animals, which later showed positive signs of regeneration, gained weight faster than their respective controls. They also reported that $33.3 \%$ of their Lidase-treated animals showed "full recovery of function" and that $57.1 \%$ had at least "partial recovery of function." We found no differences in clinical variables between treated and control animals except that treated animals weighed significantly more than controls $(p<0.05)$. Matinian and Andreasian reported that 53 of 59 treated animals, compared to 0 of 11 controls, showed a cortical evoked response after stimulation of the sciatic nerve. Their 59 treated animals were selected from all eleven of their treatment groups, including one group treated with Lidase. None of our animals showed regeneration as measured by cortical evoked potential. Since no further breakdown of their results was reported, we cannot determine which treatment group included animals demonstrating cortical evoked response. We do know that Matinian and Andreasian tested 5 of 63 animals treated with Lidase. How they selected these animals for testing and the specific result for each treatment group were not reported. Finally, our radioisotopic evaluation showed no significant difference between treated and control animals.

We cannot confirm that Lidase treatment enhances axonal regeneration. Our previous experiment [2] failed to confirm the beneficial effects of trypsinelastase or hyaluronidase-trypsin treatment combinations. The reason for the difference in results between our experiments and Matinian and Andreasian's remains unclear. Unique experimental animals, incomplete spinal cord transections, or other, unknown factors may be responsible.

Supported by Veterans Administration research support awarded to Dr Feringa and by development funds from the Department of Pathology, University of Michigan.

The authors acknowledge the technical assistance of Ms Linda Lee Austin and translation services of Dr James Pugh. Lidase was obtained from the USSR by Dr Carl Brewer of NINCDS, who kindly provided the enzyme to us for this experiment.

\section{References}

1. Alfer'eva MZ, Kuznetsova GN: Novy̌̌ preparat gialuronidaznogo dě̌stvirâ lidaza. Moscow, Vsesoiuznyi NauchnoIssledovatel'skii Institut Miasnoi Promyshlennosti. Trudy vyp 9:115-121, 1959

2. Feringa ER, Kowalski TF, Vahlsing HL, et al: Enzyme treatment of spinal cord transected rats. Ann Neurol 5:203-206, 1979

3. Matinian LA, Andreasian AS: Enzyme Therapy in Organic Lesions of the Spinal Cord. (Translated by Elena Tanasescu.) Los Angeles, Brain Information Service/BRI Publications Office, 1976

4. Nesmeyanova TN: Experimental Studies in Regeneration of Spinal Neurons. New York, Wiley, 1977

5. Pharmacy Committee of the Medical Academy of the USSR: Lidase product insert form, 26 October, 1957 